\title{
The Meaning of Mission Statements to School Practice and Professional Development: An Interpretative Phenomenological Analysis
}

\author{
Bradley Ransom \\ University of Roehampton (London) Online. United Kingdom. \\ bradley.ransom@roehampton-online.ac.uk
}

Dimitrios Vlachopoulos

Amsterdam University of Applied Sciences. Netherlands.

d.v.vlachopoulos@hva.nl

Received: 6/9/2019

Accepted: 19/5/2020

Published: 29/1/2021

\begin{abstract}
While mission statements (MSs) are included in schools often due to governing policy, evidence suggests they remain underutilized by leaders. Scant research is undertaken with regard to school mission statements and how these affects daily practice. This qualitative phenomenological study explores the extent to which school MSs influence daily practice, as well as professional development for school leaders and teachers. This study draws upon interviews with six individuals who lead or teach at two different international schools. The findings provide valuable insight into how MSs are experienced by leaders and teachers. The paper concludes with a discussion around the potential implications for policy makers and school leaders who wish to shape school culture and professional development.
\end{abstract}

Keywords: school leadership; mission statements; continuing professional development and learning; school culture

Resum. El significat de les declaracions de missió per a la pràctica escolar i el desenvolupament professional: una anàlisi interpretativa fenomenològica

Si bé les declaracions de missió (DM) s’inclouen en les escoles sovint a causa de la política de govern, la investigació actual subratlla que els líders continuen subutilitzant-les. El present estudi qualitatiu fenomenològic explora la mesura en què les DM i el desenvolupament professional influeixen en la pràctica diària de les escoles tant per als líders escolars com per al professorat. L'estudi es basa en entrevistes a sis persones que dirigeixen o ensenyen en dues escoles internacionals diferents. Els resultats proporcionen informació valuosa sobre com els líders i el professorat experimenten les DM. L'article conclou amb una discussió sobre les possibles implicacions per als responsables de les polítiques educatives que desitgen protagonitzar la cultura escolar i el desenvolupament professional.

Paraules clau: lideratge escolar; declaracions de missió; desenvolupament professional continu i aprenentatge; cultura escolar 
Resumen. El significado de las declaraciones de misión para la práctica escolar y el desarrollo profesional: un análisis fenomenológico interpretativo

Si bien las declaraciones de misión (DM) se incluyen en las escuelas a menudo debido a la política de gobierno, la investigación actual subraya que los líderes siguen subutilizándolas. El presente estudio fenomenológico explora la medida en que las DM y el desarrollo profesional influyen en la práctica diaria de las escuelas tanto para los líderes escolares como para el profesorado. El presente estudio fenomenológico interpretativo se basa en entrevistas a seis personas que dirigen o enseñan en dos escuelas internacionales diferentes. Los resultados proporcionan información valiosa sobre cómo los líderes y el profesorado experimentan las DM. El artículo concluye con una discusión sobre las posibles implicaciones para los responsables de las políticas educativas que desean protagonizar la cultura escolar y el desarrollo profesional.

Palabras clave: liderazgo escolar; declaraciones de misión; desarrollo profesional continuo y aprendizaje; cultura escolar

\section{Summary}

1. Introduction $\&$ rationale

2. Methodology

3. Findings
4. Discussion and conclusions

Bibliographical references

\section{Introduction $\&$ rationale}

Purpose. Why. Raison d'être. Giving schools meaning and direction, vision and mission statements (MSs) serve to unify stakeholders in achieving student growth through learning. Teachers can also nurture their own growth in knowledge and skills through professional development, which intends to directly or indirectly advance student achievement. MSs convey the vision and goals of an organization, which in the case of schools, concerns the improvement of education outcomes for all children, if not the entire school community. However, a growing body of literature suggests a missing link between theory and practice, or vision and reality (Gurley, Peters, Collins \& Fifolt, 2015), which raises considerable implications for policy makers and education leaders, particularly as accountability rockets while budgets plunge. To seal this fissure, teachers must incorporate continuous professional learning in the school mission, by reflecting, collaborating, researching and problem-solving. Next, leaders must clearly support and articulate MSs to encourage continuous learning for both students and teachers, while being cognizant of fiscal resources.

The essence of school MSs serve to develop the skills and capacity in students as lifelong learners, which would ideally galvanize teachers to actively pursue Continuing Professional Development and Learning (CPDL). Teachers desire student progress just as CPDL strives for teacher growth, so the MSs must construct and maintain a shared vision of learning and development. In the business sector, MSs have enjoyed ample research attention, with a focus 
on the relationships between organizational culture and employee output (King, Case \& Premo, 2012; Babnik, Breznik, Dermol \& Širca, 2014). In comparison, school MSs have received sparse interest (Stemler, Bebell \& Sonnabend, 2011; Ayers, 2015), while failing to provide an in-depth qualitative analysis of how MSs manifest in daily practice. In contrast to MSs, the topic of CPDL is associated with a large and growing body of literature, gaining further momentum via popular informal platforms of professional development such as social media (Sie et al., 2013; Ross, Maninger, LaPrairie \& Sullivan, 2015; Stevenson, Hedberg, O’Sullivan \& Howe, 2016; Vlachopoulos $\&$ Makri, 2019), and calls to increase research-based practice in schools (Cordingley, 2015). Only two studies to date link faculty development to school vision (Legorreta, Kelley \& Sablynski, 2006). However, the specific link between MSs and CPDL has otherwise received little attention, and coinciding with calls for more research to qualitatively investigate MSs in daily practice, we embarked upon this study to attempt to fill the void.

The present study was designed to explore the meaning educators ascribe to MSs in daily practice and professional development. A phenomenological analysis examined the "lived experience" of leaders and teachers in detail, highlighting the ways in which MSs are perceived in school culture (Smith, Flowers \& Larkin, 2009, p. 11). This study asked educators to reflect on how alignment to their MSs may affect school culture with regards to the common goal of growth and learning. Examining multiple contexts and perspectives of the shared phenomenon can illuminate workflows of MS communication, or unearth undesirable gaps or issues such as "mission creep", whereby teachers are not aligned to specific common objectives (Slate, Jones, Wiesman, Alexander \& Saenz, 2008, p. 26). Furthermore, with this understanding, researchers can distinguish grounds to conduct alternative qualitative analysis related to MSs, daily practice, and CPDL.

The primary research question in the study is: What meaning do leaders and teachers ascribe to mission statements in daily practice and professional development?

The secondary research questions are as follows:

1. What do mission statements mean to leaders?

2. What do mission statements mean to teachers?

3. How do mission statements manifest in daily practice?

4. How do mission statements connect with formal professional development?

5. How do mission statements connect with informal professional development?

\section{Methodology}

By way of phenomenology, this qualitative study aims to interpret the perceptions of teachers and leaders in their experience of MSs in daily practice and 
professional development. Robust methodologies were designed to protect the integrity of the study, educational research, affiliated organizations, participants, and associated sites (Teddlie \& Yu, 2007). Prior to data collection, ethical procedures were strictly followed to obtain Institutional Review Board clearance.

For this study, two mixed gender, K-12, internationals schools located in Manila, Philippines will henceforth be referred to as School A and School B. School A is located in Manila, Philippines, with 350 students aged 3-18. Its mission statement is short with a narrow focus for promotion of a specific culture and language acquisition in particular. Moreover, it specifically aims to attract families as a result of that specific culture and language. School B is also located in Manila, Philippines, with 950 students aged 3-18. The mission statement is long and detailed with intention and value statements that promote community learning, health, and global citizenship. Both schools have MSs focused on learning and achievement, just as state schools would but they further characterize their cultural origin (e.g. American, French, Chinese) and celebrate global citizenship. Both A and B share similar MS components that speak to holistic, individualized education of international repute. However, there are differences in the scope and detail. The School A MS is short with a narrow focus for promotion of origin culture and language acquisition. Moreover, it aims to attract families as a result of that specific culture and language. School B's MS is long and detailed with clear intention and value statements that promote community learning, health, and global citizenship. While the schools were polarized in structure and culture, every participant in this study (Table 1) held at least 12 years of teaching experience, allowing them to provide rich information to interpret the MS in the context of their school culture and professional development.

Table 1. Participant information

\begin{tabular}{|c|c|c|c|c|c|c|}
\hline Pseudonym & Fiona & Justin & Bruce & Ron & John & Luke \\
\hline School & A & A & A & B & $\mathrm{B}$ & B \\
\hline $\begin{array}{l}\text { Role } \\
\text { Senior Leader (SL) } \\
\text { Middle Leader (ML) } \\
\text { Teacher }(\mathrm{T})\end{array}$ & SL & $\mathrm{ML}$ & $T$ & SL & $\mathrm{ML}$ & $\mathrm{T}$ \\
\hline Host or expat $(\mathrm{H} / \mathrm{E})$ & $\mathrm{H}$ & $\mathrm{E}$ & $E$ & $\mathrm{E}$ & $\mathrm{E}$ & $\mathrm{E}$ \\
\hline Years of teaching & 14 & 13 & 15 & 30 & 12 & 20 \\
\hline Years at school & 11 & 7 & 2 & 23 & 6 & 16 \\
\hline Years in current role & 5 & 5 & 2 & 12 & 4 & 16 \\
\hline
\end{tabular}

Source: Own elaboration.

Semi-structured interviews were conducted to encourage an open, expansive and detailed account (Smith et al., 2009). Data underwent interpretive phenomenological analysis (IPA) which is underpinned by the lived experiences of participants yet interpreted through the meaning found by the analyst in a hermeneutic reduction process. To achieve data saturation and reveal meaning, the following process was followed: 
1. Immersive and numerous reading of transcripts.

2. Initial noting of content with detailed comments.

3. Themes and patterns developed.

4. Connection of themes.

5. Bracket participants and move to next case.

6. Look for across case themes and re-order to theoretical level (Smith et al., 2009).

\section{Findings}

A total of 269 significant statements were identified from the six transcripts. Table 2 provides examples of significant statements along with their respective meaning. Table 3 presents theme clusters and associated meanings. It is not the intention of this analysis to make a comparison between the two; however, the reader should be cognizant that one school (School B) had clear organizational identity, MS awareness, and a professional development strategy. The other school (School A) had an entirely different organizational culture, which was not influenced by its MS, nor did it report a clear strategy for CPDL, other than mandated training.

While there were distinct cultural differences between school A and B, participants also drew from their prior experience, which contributed to clear

Table 2. Example of significant statements and formulated meaning

\begin{tabular}{ll}
\hline Statement & Meaning \\
\hline Luke, "more people get a slice of the pie." & Appreciation for learning community shift. \\
\hline Ron, "in the forefront of what we do". & MS communication is a vital "culture" tool. \\
$\begin{array}{l}\text { John, "the students do an amazing job". } \\
\text { Inspired by students and how they model the } \\
\text { MSs in daily practice. }\end{array}$ \\
\begin{tabular}{ll} 
Fiona, "before, it's like, I'm here to teach. That's & $\begin{array}{l}\text { Transition to leadership-initiated value placed } \\
\text { on the MSs. }\end{array}$ \\
$\begin{array}{l}\text { Justin, "that's about me. That's what I do. Or } \\
\text { that's something I should do". }\end{array}$ & $\begin{array}{l}\text { Connection to the MSs can encourage motiva- } \\
\text { tion or accountability. }\end{array}$ \\
\hline
\end{tabular}
\end{tabular}

Source: Own elaboration.

Table 3. Examples of theme clusters and associated meaning

\begin{tabular}{lll}
\hline $\begin{array}{c}\text { Superordinate } \\
\text { theme }\end{array}$ & \multicolumn{1}{c}{ Clusters } & \multicolumn{1}{c}{ Meaning } \\
\hline Clarity & - Awareness & Clarity for stakeholders is achieved by increas- \\
& - Communicated expectations & $\begin{array}{l}\text { ing awareness of the MS. "Key drivers" are } \\
\text { - Key drivers }\end{array}$ \\
- Decision making & sommicated to model expectations for all \\
& - Recruitment & MSs are tools that can be used to attract and \\
- Parents & filter leaders, teachers, parents, and students \\
Tool & - Accountability & to a school's cultural expectations. Account- \\
& - Student learning & ability can be reinforced at different stages of \\
& - Key stage differences & students', teachers', or leaders' careers. \\
\hline
\end{tabular}


themes in the meaning of their lived experiences of MSs in daily practice and professional development. The four superordinate themes of clarity, weight, affinity, and culture are discussed in the context of participant meaning in this study.

\section{Theme 1. Clarity}

Any mainstream culture requires a clear purpose; accordingly, MSs with little influence present a "difficult" and "frustrating" void. Fiona, a senior leader believed the MSs "should be a reference point". Justin, a middle leader, felt that the MSs "needs to be more visible ... not just visible but referred to". Reflecting on his prior experience at a different school, Justin visualized a jigsaw in which individuals fit with community goals: "people could see how they had ... a role to play within reaching the mission". A clear awareness and prevalence of MSs within a school communicated expectations across the array of stakeholders. Experienced senior leader, Ron, had a clear sense of stewardship towards the MSs and proudly employs "key drivers" via multiple avenues to promote clarity.

Luke prefers clarity of MS purpose to be achieved via other communication modes, which he likens to creative interior design, "that might then articulate [the MSs] among [the] audience". While Luke believes in creatively layering key messages regarding purpose, John prefers to be explicit:

There was definitely a number of meetings that [the principal] ran ... so it's obviously something ... he felt it was important that people engaged with [it]. I think that some teachers kind of thought, 'What the hell am I doing here, I've got stuff to do? Can't you just tell us what the mission and vision is and I'll get on and do it?' But actually I thought that's quite [a] powerful message to the teaching staff.

Showing John's perception of other teachers' feelings mirrors Luke's reticence toward a direct approach. However, in a similar vein to John, class teacher Bruce, was invigorated by the process of developing MSs which had the potential to transform the stakeholders:

It started out just as another meeting ... it ended up being a very helpful ... activity that we did ... the teachers' opinions and thoughts were valued and included ... you helped to build this and now we can start to implement it.

Similarly, Fiona reflects back to her past experience at another school that had a clear identity, and also references the experience in this way: "it was just clear and you know where we're going". The participants all valued clarity and respected that MSs should be clear, whether directly or through more subtle messaging. 


\section{Theme 2. Tool}

Participants either made direct links to the MSs being utilized to meet purpose, or described experiences where leaders had shaped decisions directly linked to the MSs. Some individuals were reluctant to see MSs as tools but used them as such with students, or as leverage for CPDL, for example. Some participants would have liked to have used them, but found the support was not available at the time which would have added the required "weight". At the other end of the spectrum, MSs were seen to be strategically employed. Ron uses the MS as a policy benchmark to maintain the integrity of school goals, stating "[parents] need to be on board with that ... and that's inherent in our vision and mission and they have to understand ... what they are signing into". As a middle leader, John also uses the MS for specific purposes:

See it lends more weight doesn't it? It's like, 'look it's not just me saying this, this is what the school is about. You know, I'm talking to you about your lesson and I have my personal opinion and I'm your line manager so it counts for a little bit more but actually

$\ldots$ this is the reason for the school being here $\ldots$ and if you're not doing that bit [in] your lesson, then you're missing your little bit of the jigsaw puzzle ... and it needs to be there.

Justin reflects on past experience at a school where the MSs "played a huge part in the school's identity and the culture and values of the school". However, in his current school context, Justin feels he can still go about his job without the support or influence of MSs, while also acknowledging that MSs are important, or at least that he has seen them make an impact in his past experience.

Fiona wishes to wield the MS as an effective tool, stressing "the only way ... for it to become alive is to use it". As a leader, Fiona desires to align pedagogy and practice through CPDL, but struggles with the lack of common focus, accountability, and school-wide strategy for anything beyond mandated professional development:

My solution is to have someone train all these teachers to execute that ... but since we don't have [CPDL], and we have teachers who are very stubborn ... 'this is my way, this is what I wanted to do'. It's quite difficult ... it affects the program, from the way I see it.

In the theme of clarity, Bruce experienced leadership which engaged MSs as a tool to transform teacher engagement. Equipped with a sense of shared purpose, Bruce was then able to 'tool up' and target student engagement as "the kids were able to ... help to support this mission statement". Going further, Bruce describes a viral application of MSs that he immediately linked to other stakeholders:

The administration is caring about professional development, they are representing the school mission value as well so they're doing it, we're doing [it] 
and were engaging students so they can be part of it. And then I think from there again it will spread. The parents are going to be more willing to [engage] $\ldots$ if the school is actually taking their vision seriously.

Luke's preference to distance himself from direct MS quotes, which emerged in the first theme, evolved in the course of his interview. Luke used "key drivers" of the MSs to influence the curriculum: "it's allowed me the opportunity to change ... the direction of this learning they're currently doing which is [going to] be the tip of the [iceberg]". Moreover, Luke plans to employ the MSs as a lever to impact school policy, "it's given me leverage to make a big change

... it's a small change but will have a big impact". A personal connection to the MSs is the essence of the next theme.

\section{Theme 3. Affinity}

Each participant had experienced specific connections to MSs, and it was during these moments that relevance and meaning was piqued. Participants in managerial positions presented a focused perspective of MSs, and in particular their potential as tools and cultural drivers. Bruce values the necessity of "buy in," so that the MS can be "meaningful to the learning community ... not ... something that's just there for show but rather something that's used in the school". Bruce, then contrasts his current experience, which is characterized by a lack of connection to the MSs, to the past: "if the values are there, you see the values and everybody is buying into the system of what the school represents then you're [going to] want to fit in if it matches".

Fiona had not even realized that her current school had any MSs until she came across it as part of her leadership responsibilities, specifically regarding her school's accreditation. New to her role, Fiona "felt bad" about the oversight, but rationalized that the prevailing culture had long been one that paid little mind to MSs: "I did not do this. You [accreditation team] were visiting and checking for the past few years. You know what I mean? so I realized OK $\ldots$ it was bad but we can do something about that". Since establishing her leadership position, the MSs have become a desired but elusive tool for Fiona: "before, it's like, I'm here to teach. That's it. That was it". Fiona's affinity to the MSs is nevertheless growing, she has a clear desire to leverage them, but faces the task of bringing the teachers round to this concept that is unfamiliar to the school.

Like Bruce and Fiona, Justin contrasts past experience in schools that had clarity of purpose and were supported by distinct organizational identities. $\mathrm{He}$ reflected that, in his current school's MSs, he "would expect to see something in there, a sentence or even phrase that I think that's about me. That's what I do. Or that's something I should do". Justin wants a direct connection to the MS but also alludes to the significance of professional expectations and social norms. 
From a different point of view, Ron's personal mission is to ensure every stakeholder has an affinity to the school's MSs. An approach which is evident in the language he uses to describe the MSs, which is as an unwavering influence on his daily practice: "vision mission is not just sits [sic] on a wall, it's something that you put into practice and you live .... and die by". Affinity to MSs is something Ron also looks for when recruiting: "[A] candidate that fires off an application that's not even bothered to look at [our MSs], delete". In this statement we see a direct relationship between themes of tool, and affinity, which is also clear in John's experience.

As previously stated, John's affinity to MSs has "helped" him shape department policy, and to clarify pedagogical decisions. John was fortunate to have many inspiring colleagues that he strived to "emulate" in a school that also had a clear identity and strategic purpose as a learning community. John's old colleagues seemed to have a sense of a learning community, whether their mission statement was part of this or not, nevertheless John's fondness for the "many fantastic practitioners" is richly represented in his narrative.

Driven by the word "sustainability", Luke's epiphany is revealed: "it's given me ... an affinity with the vision mission statement ... it's given me a focus. It's realigned me with what it is". Many mission statement components, Luke feels, are "obvious and what you should be doing anyway", but "sustainability" and "compassion" have "caught [his] interest recently". Luke's newfound connection to these words within his school's mission statement have inspired him to want to "tweak" the current wording as essentially it would be a "very powerful word". Or, as John may argue, a tool that "adds more weight". Luke appears unsure if his affinity to this key driver of MSs is beginning to affect his personal life. He is an experienced teacher who had found a "controlled" work-life balance but his personal "affinity" to the sustainability element of School B's MSs begins to draw energy from his personal interests to fuel daily practice. This alignment with MSs, albeit specific, is something that has so far enhanced his teaching, but he also has hopes for a wider impact, i.e. to leverage MSs to affect school culture via school policy.

\section{Theme 4. Culture}

Participants gave rich past or present examples of cultures with clear identities forged through MSs. The participants all believed in the power of "meaningful" MSs shaping the identity and daily practice (culture) of a school. While not always explicitly expressed, 'where we are going' was clear and palpable, and the MSs were being lived or "modelled", by students and teachers.

John expressed, "[for] the most part ... teachers [and] students communicate [the MS] through their actions". But at crucial times of the year, with older students participating in a high-stakes exam system, John tempered the former statement, saying "we have to be realistic". Nevertheless, he appreciates the prevailing culture, which is often expressed through community behaviour: 
people talk about community here a lot, [it] is a very strong community, and people ... go the extra mile without even realizing it. I go to assemblies ... I see incredible stuff from primary school up, that I think really shows, [it's] one of the best places to come and see the vision in [action].

John often talks of "learning conversations", or language that is part of the culture and represents the expectations from the community members. John is clear on the "significant" trend that is building in the learning culture. From John's perspective, the prevailing culture, which attributes an important role to the learning community and CPDL, is due to current school leadership who have prioritized the school MSs, as well as a culture of learning for both students and teachers. This school's cultural momentum is cultivated by committed leadership, policy, and social identity:

There is that inbuilt expectation that people are keeping themselves up to date ... you'll go around campus [and] there are learning conversations going on all the time ... it's very much a driver of what we do as a school. We feel that everything we talk about is ... learning.

Luke also appreciates the growth of shared learning, whose passion for sustainability was directly attributed to CPDL. Luke expressed the growth as a benefit to all: "I feel that there is a wider ... array of options and of opportunity, but more importantly I think it's reaching [further] so more people get a slice of the pie" - He is confident the administration made a "school investment" that carried a wider impact, explaining "I got so inspired, I learnt new skills, these skills are spreading".

Differing perceptions of school culture were held, both negative and positive. Participants whose school had a muted identity had low expectations of what could be achieved, but also felt that there was potential do more should the circumstances be right. Bruce posited, "If you don't feel part of the learning community, you're not really going to want to do so much for the school ... you're not going to be motivated ... [or] want to make it a better place". Meetings were seen as a waste of time by Justin, who wanted more pedagogical engagement as a community, saying "people like learning and or doing something and achieving something". Fiona was hopeful about the potential of CPDL as a future element of her school's culture: "I was hoping even as a school we can have something like a [PLC] ... because that's what I experienced in my previous school". Culture is thus seen as something malleable, whether the participants are merely hoping for positive change or actively planning for it.

\section{Discussion and conclusions}

For leaders, MSs have the potential to be an effective tool in shaping identity and culture by communicating expectations and values. Ron, in particular, handles this tool like a craftsman, methodically applying it to strategically fashion school culture and everyday practice (Drucker, 1974; King et al., 
2012). A tool such as a MS can be used specifically to provide clarity in a range of situations, such as ensuring prospective parents understand a school's social norms and policies prior to enrolling their children. MSs can also be used to ensure prospective teacher alignment with the school's cultural and social norms. John used the school MSs to guide the design of his team's department goals. He used the design process to create affinity towards the MSs and delineate accountability expectations, thus creating change within his department and further raising teaching and learning standards. Although John is not yet at Ron's expert level, he still confidently wields MSs as tools of accountability, that are given further "weight" by the backing of senior leaders.

Like John, Fiona connected more explicitly with a sense of common purpose and clear objectives when she was placed in a leadership position. She felt hopeful yet disempowered, due to the school's lack of identity, and stressed the importance of applying MS wording in practice, to "use" them for all stakeholders. Justin was an anomaly in the sense that he did not consider MSs as tools to use with his teaching staff. He did, however, make a connection between the MSs and accountability, in what he "should be doing". Both leaders at School A conveyed a sense of disempowerment. Justin viewed himself as someone who just taught at the school, but agreed that MSs have the potential to impact commitment and school culture. Fiona, wanted to use MSs strategically as tools to provide clarity (Tahir \& Howard, 2003), but did not feel supported by the school leaders or her peers. While affinity is an expectation at any school that uses its MSs, leaders also see MSs as valuable tools that should shape expectations and school culture. Conversely, in a school that does not adequately deploy its MSs, the end result is leaders who, at best, are left with a notion of their potential "power".

On the surface, this issue has parallels with the study of Camiré, Werthner $\&$ Trudel (2011), who found that awareness of MSs dissipates through stakeholder levels. However, both teachers in this study had connected with their school MSs, but also felt more than able to teach without it. Bruce argued that schools can function without MSs to impact daily practice, and that teachers will continue to do what they believe is right for the students. While Bruce is confident that his students will be fine regardless, this lack of shared school vision echoes the question posed by Gurley et al. (2015) regarding the vagueness of unaligned school cultures. That said, Bruce shared his affinity towards MSs from past experience, and spoke of the potential if MSs were to be employed as tools to affect school culture and student learning.

Luke shared Bruce's notion that students would be fine when taught without overt reference to school MSs, however, his newfound affinity also caused Luke's professional identity to evolve - he now intends to use components of the school MSs to advocate for decisions that should benefit both student learning and the community as a whole. For teachers to "buy in", personal affinity is key. As Fiona and John indicated, early in their careers as teachers, they had a connection to and learned from the more established professionals. Whereas for Bruce and Luke, as experienced teachers, affinity at first glance 
appeared organic. For both, leadership was used to either involve teachers in MS development (Bruce) or as a tool to promote or approve CPDL (Luke). To summarize, MSs can easily be "left on the page", by even the most conscientious and caring professionals who will use their best judgement to help their students be successful. However, a direct affinity to the MSs increases the potential for both student and teacher learning.

In this study, MSs affected daily practice heavily in School B, with participants experiencing and modelling them for themselves and others. For Ron, MS clarity is essential in ensuring all stakeholders are aware of the "key drivers" that strategically shape school culture. This was also evident in John's use of, and reference to, the principal's "powerful message" about the MSs that provided the middle leader with gravitas to use MSs in his role, thus shaping and extending that aspect of school culture. It's clear and consistent messages such as these that are infused throughout the school and community, modelled by students in assemblies and in their day-to-day actions and language (Bennett, 2017).

Making reference to his past experience, Bruce shared the potential of MSs to affect school culture, describing the transformation from the time he and his colleagues had contributed to MS development at his previous school. Affinity to MSs and their effects on school culture were thus evident: teachers could feel their voice was being heard, leadership were providing support, and teacher's input was valued. This kind of involvement supports much of the research that urges for stakeholder involvement in MS development to provide a meaningful connection and motivate desired action (Desmidt, Prinzie \& Heene, 2008; Panda \& Gupta, 2003; Babnik et al., 2014; Bhavesh, Lorne, Hazel-Melanie \& Chris, 2015).

Luke shared Bruce's notion of professional integrity, but advocated that most MS components are already in place. It was later in the interview that Luke made the connection that leadership may have applied "key drivers" strategically. A consistent message across School B interviews was that while students were not able to recite MSs word for word (although some could), they all understood the key drivers which shaped their learning culture. It is here that a connection between self and community can be drawn (Erikson, 1968). The power of words and clarity can thus be achieved through social norms and behaviours, as individuals strive for favourable dynamics, and to reinforce organizational identity (Ashforth \& Mael, 1989).

For Fiona, Bruce, and Justin, the MSs did not manifest in daily practice at their current school, and the prevailing culture was shaped, at least in part, by this lack of strategic direction (Slate et al., 2008). However, each of the aforementioned had had experiences of schools with strong organizational identity that were influenced by MSs. Other factors of organizational identity and daily practice that were shared by all the participants related to professional development.

School B has a clear CPDL strategy, which was both entrenched in and emanated from, their MSs (Sarros, Sarros, Cooper \& Santora, 2016). School B participants consistently identified themselves as a "learning community", 
which was conveyed through both action and language, in phrases such as "learning conversations", and "[a] wider net being cast". Formal CPDL budgets in School B were approved only if the requests aligned with key drivers in the MSs. A strategic change in policy meant that more information and learning was made available or shared between stakeholders to deliberately impact teacher and student learning. For example, Ron stressed that MS components must be strategically implemented through professional development programs, for two reasons: "one, to buy-in, but two, to have the skills and tools to be able to deliver". Interestingly, however, both John and Ron indicated that they have to be quite selective in their choice of formal CPDL, as they are often ahead of the vast majority of attendees and already up-to-date in terms of knowledge and practice. John appreciates CPDL opportunities, but also feels frustrated at the level of conversation with external teachers and leaders, who are ultimately not as engaged with their MSs, but simply seeking to tick administrative boxes to comply with accreditation requirements. In this instance, School B was wary of sending participants to pursue formal professional development, not only due to the lack of impact on school return, as Luke stressed (Walton, Nel, Muller \& Lebeloane, 2014), but also due to doubts around the quality of the course itself as well as the competence level of other participants. The unwavering focus on and clarity of vision around teacher and student learning at School B shows the ideal qualities of a genuine school-wide PLC (Bolam et al., 2005; Dufour \& Fullan, 2013).

In School A, Fiona, Justin, and Bruce had also taken mandatory professional development programs, without any resulting discernible value or effect on strategic planning (Kragler, Martin \& Kroeger, 2008). Fiona and Bruce were particularly rueful in their nostalgic comparisons, where MSs were used as tools to provide organizational clarity and embed CPDL into the fabric of daily practice.

Affinity is the most relevant theme in informal professional development. Unless MSs are used as tools to provide clarity around 'who we are and what we do,' there can be no implied expectation of stakeholders regarding social dynamics (Ashforth \& Mael, 1989). Such dynamics are key in the potential to drive motivation to spend extra time learning. School B leadership deliberately crafted a specific culture that permeated their "learning community" in many ways, chiefly through "learning conversations", "books", and "Twitter". Ron models informal professional development by reading books and sharing his findings, a practice or habit that becomes the social norm. John found his informal professional development engagement has expanded throughout the school; he attributed this growth to the principal and his commitment to CPDL, which is directly linked to the MSs. To categorize the School B "learning community", we can certainly call it a CoP that effectively transforms its members via informal professional development (Wenger, 1998). Through a clear school culture, communicated via "key drivers", School B has been able to increase the potential of stakeholders' affinity to MSs. Simple math, but in this case informal CPDL can be successfully connected to the MSs. 
When a school that does not connect the MS to anything other than the paper on which it is printed or the web page it adorns, the impact is minimal. Informal professional development at School A was the self-serving kind, designed to narrowly meet the needs of a role or situation. For example, Bruce cited behaviour, and Fiona mentioned a role-based Facebook community. Justin accessed subject-specific resources but did not mention passing knowledge or information on to his peers. None of these informal pursuits should be dismissed, as they are all valid and relevant to the needs of the individuals. Nevertheless, there was a telling lack of connection between informal professional development and the school MS. That said, School A participants all wished for a future in which a clear CPDL strategy was established to motivate them further (Prenger, Poortman \& Handelzalts, 2017). As Stevenson et al. (2016) suggest, leaders must promote innovative ways to motivate teachers to participate in informal CPDL.

\section{Bibliographical references}

Ashforth, B. \& Mael, F. (1989). Social identity theory and the organization. Academy of Management Review, 14(1), 20-39.

Ayers, D. F. (2015). Credentialing structures, pedagogies, practices, and curriculum goals: Trajectories of change in community college mission statements. Community College Review, 43(2), 191-214.

Babnik, K.; Breznik, K.; Dermol, V. \& Širca, N. (2014). The mission statement: Organisational culture perspective. Industrial Management \& Data Systems, 114(4), 612-627.

Bennett, T. (2017). Creating a culture: How school leaders can optimise Behaviour. London: Department for Education. Retrieved from: <https://www.gov.uk/government/publications/behaviour-in-schools>

Bhavesh, S.; Lorne, D.; Hazel-Melanie, R. \& Chris, B. (2015). Mission statements and performance in non-profit organisations. Corporate Governance, 5, 759-774.

Bolam, R.; McMahon, A.; Stoll, L.; Thomas, S.; Wallace, M.; Greenwood, A.; Hawkey, K.; Ingram, M.; Atkinson, A. \& Smith, M. (2005). Creating and sustaining professional learning communities. London: Department for Education and Skills.

Camiré, M.; Werthner, P. \& Trudel, P. (2011). Mission statements in sport and their ethical messages: are they being communicated to practitioners? In R. Schinke (Ed.). Introduction to sport psychology: Training, competition and coping (pp. 111-121). Hauppauge, NY, US: Nova Science.

Cordingley, P. (2015). The contribution of research to teachers' professional learning and development. Oxford Review of Education, 41(2), 234-252.

Desmidt, S.; Prinzie, A. \& Heene, A. (2008). The level and determinants of mission statement use: a questionnaire survey. International Journal of Nursing Studies, 45, $1433-1441$.

Drucker, P. (1974). Management: Tasks, responsibilities, and practices. New York, NY: Harper \& Roe.

Dufour, R. \& Fullan, M. (2013). Cultures built to last: Systemic PLCs at work [Kindle edition]. Bloomington: Solution Tree Press.

Erikson, E. H. (1968). Identity. New York, NY: Norton. 
Gurley, D.; Peters, G.; Collins, L. \& Fifolt, M. (2015). Mission, vision, values, and goals: An exploration of key organizational statements and daily practice in schools. Journal Of Educational Change, 16(2), 217-242.

King, D.; Case, C. \& Premo, K. (2012). An international mission statement comparsion: United States, France, Germany, Japan, and China. Academy of Strategic Management Journal, 11(2), 93-119.

Kragler, S.; Martin, L. \& Kroeger, D. (2008). Money down the drain: Mandated professional development. Journal of School Leadership, 18(5), 528-550.

Legorreta, L.; Kelley, C. \& Sablynski, C. (2006). Linking faculty development to the business school's mission. Journal of Education for Business, 82(1), 3-10.

Panda, A. \& Gupta, R. (2003). Why mission statements become a show piece? Case of an Indo-American joint venture. The Journal for Decision Makers, 28(2), 23-47.

Prenger, R.; Poortman, C. \& Handelzalts, A. (2017). Factors influencing teachers' professional development in networked professional learning communities. Teaching and Teacher Education, 68, 77-90.

Ross, C.; Maninger, R.; LaPrairie, K. \& Sullivan, S. (2015). The use of Twitter in the creation of educational professional learning opportunities. Administrative Issues Journal: Education, Practice, and Research, 5(1), 55-76.

Sarros, J.; Sarros, A.; Cooper, B.; Santora, J. \& Baker, R. (2016). Board and senior management alignment on school strategy. Educational Management Administration \& Leadership, 44(3), 451-466.

Sie, R.; Pataraia, N.; Boursinou, E.; Rajagopal, K.; Margaryan, A.; Falconer, I.; Bitter-Rijpkema, M.; Littlejohn, A. \& Sloep, P. (2013). Goals, motivation for, and outcomes of personal learning through networks: Results of a tweetstorm. Journal of Educational Technology \& Society, 16(3), 59-75.

Slate, J.; Jones, C.; Wiesman, K.; Alexander, J. \& Saenz, T. (2008). School mission statementsand school performance: A mixed research investigation. New Horizons in Education, 56(2), 17-27.

SMith, J. A.; Flowers, P. \& LARKIN, M. (2009). Interpretative phenomenological analysis: Theory, method and research [Kindle edition]. Thousand Oaks, CA: Sage.

Stemler, S.; Bebell, D. \& Sonnabend, L. (2011). Using school mission statements for reflection and research. Educational Administration Quarterly, 47(2) 383-420.

Stevenson, M.; Hedberg, J.; O’Sullivan, K. \& Howe, C. (2016). Leading learning: The role of school leaders in supporting continuous professional development. Professional Development in Education, 42(5), 818-835.

TAHIR, S. \& HowARD, L. (2003). Mission statements exposed. International Journal of Contemporary Hospitality Management, 15(5), 255-262.

Teddlie, C. \& Yu, F. (2007). Mixed Methods Sampling: A typology with examples. Journal of Mixed Methods Research, 1(1), 77-100.

Vlachopoulos, D. \& MaKri, A. (2019). Online communication and interaction in distance higher education: A framework study of good practice. International Review of Education, 65(4), 605-632.

Walton, E.; Nel, N.; Muller, H. \& Lebeloane, O. (2014). "You can train us until we are blue in our faces, we are still going to struggle": Teacher professional learning in a full-service school. Education as Change, 18(2), 319-333.

Wenger, E. (1998). Communities of practice: learning, meaning, and identity [Kindle Edition]. New York: Cambridge University Press. 